\title{
MANAGEMENT
}

Received:

14 May, 2019

1st Revision:

30 May, 2019

Accepted:

3 June, 2019
UDC: $\mathbf{6 5 8 . 8 1 7}$

DOI https://doi.org/10.26661/2522-1566/2019-2/08-02

*Corresponding author email: yafetekal@gmail.com

\section{CUSTOMER REPURCHASE INTENTION IN SERVICE BUSINESS: A CASE STUDY OF CAR REPAIR SERVICE BUSINESS}

\author{
YAFET EKA PRASETYA, Magister Management Blended Learning Program, Binus University, \\ West Jakarta, Indonesia, ORCID ID: https://orcid.org/0000-0003-2343-3530 \\ JULFREE SIANTURI, Magister Management Blended Learning Program, Binus University, \\ West Jakarta, Indonesia, ORCID ID: https://orcid.org/0000-0001-6002-9196
}

Abstract. The aim of this study is to determine the relationship between behavioural intention with customer repurchase intention, customer satisfaction, perceived service quality, perceived product quality and perceived price fairness in automobile industry, particularly in service garage. This study is specified at particular authorized automobile workshops in Indonesia. The non-probability purposive sampling was performed to obtain the samples of this research. Methodology: the survey was conducted online, using the main instrument of the data collection - the questionnaire which was adopted from previous researchers. The samples were obtained from a survey conducted for two weeks with 174 respondents. The four set of variables were then tested to ensure the validity and reliability along with the assumption test to ensure the normality, linearity, homoscedasticity and multi-collinearity, which was concluded as powerful enough to be used for this research. The statistical analyses results have supported all hypotheses stated in the research. As a result the study found positive and significant relationship of perceived service quality, perceived product quality, and perceived price fairness with customer satisfaction. In addition, in the second stage, customer satisfaction was also proven to have significant and positive relationship with repurchase intention. This study can be improved by adding the sample numbers, enlarge the samples with different car brands, and have further study on additional dependent variables. However, the current result has provided valuable inputs for automobile service garage to increase the customer repurchase intention.

Keywords: customer repurchase intention, customer satisfaction, perceived service quality, perceived product quality, and perceived price fairness

JEL Classification: M21, M31, M30.

\section{INTRODUCTION}

The importance of this study was promoted in the frame of broader problem where company or car repair services spend most of their energy and fund to attract new customers as the importance of retaining customers who were left behind. A previous study by Dawkins and Reichheld, 1990 showed 5\% enhancement rate in retention led to an increase in the net present value of customers between $25 \%$ and $85 \%$ in a wide range of industries, from credit card to insurance brokerage, and from motor services to office building management. The target of retaining customers is commonly coming from loyal customers, which is normal since the most probable customers visiting the company are the loyal customers. 
Yafet Eka Prasetya and Julfree Sianturi (2019). "Customer repurchase intention in service business: a case study of car repair service business", Management and entrepreneurship: trends of development, 2 (08), pp. 18-34. doi: https://doi.org/10.26661/2522-1566/2019-2/08-02

Unlike the automobile selling in which the customers will probably return in three to four years, car repair services have privilege of frequent visit from customers related to the needs of their car repair, routine service, or accessories upgrade. The period after buying new car until customers repurchase again in three or four years later is a potential period for automobile dealers to sell their car maintenance services. However, the customers might have more options to bring their car for maintenance in different car repair dealers, either authorized or unauthorized. This is the challenge for automobile dealers to keep their customers bring their car or maintenance service in their dealers. Thus, the researchers choose the study on this sector as the available data that sufficient, thought and able to deliver added value to the related business.

In order to make customers repurchase and repeat their order to the same automobile dealer. Hussain et al. (2011) said that a business must increase its customer satisfaction level by either lowering the expectation of the customers or improving the customer perception of its service. When the services elicit satisfaction and contentment from the customers, Bowman and Narayadas (2001) in (Hussain et al, 2011) said that they will normally return to the provider and may bring along friends and colleagues, who can be potential customers. In contrary, dissatisfied customers will share their experience with others and an enterprise may never know the unexpected occurrence in the future. In today's competitive environment, keeping customer satisfaction level is very important for business to obtain customer loyalty and possible repurchase within the same outlet.

To increase customer satisfaction level for car repair business in automobile sector, automobile services need to increase the quality of after sales (Hussain et al., 2011). Service quality is an important outcome of comparison between customer expectations, both before and after their experience of service (Groonroos, 2007 in Ismail and Yunan, 2016). If the customer expectation of service performance conform their perception of service, it may lead to an inducement of service quality (Groonroos, 2007). Perceived service quality is customers' judgment regarding the overall excellence or superiority of a service (Zeithaml, 1998). Customersperceive the quality of service based on the overall experiences of a service. When customersare satisfied with the quality of the service, it will invoke an intention to repurchase the service or product.

Consumers have several perceptions about the superiority of a product, since a superior product will ensure the product reliability, sustainability, and durability (Saleem et al, 2015). Customers buy a product to satisfy their needs and expect a good quality product. If the product's actual outcome goes beyond their expectation, the consumers will be satisfied and may plan to repeat the order. In the contrary, when the product evokes disappointment, it will generate a negative response not to buy the product anymore. Customers already have preconceived notions about quality of product, price, and appearance before purchasing it. Saleem et al. (2015) said that after using a product, purchase intention may increase or decrease depends on the quality of the product and the benefits that the customer receives. If the quality is high, then repurchase intention is also high.

Most customers will compare the benefits of service that they get with the money they spend to determine whether the service is worthy or not. Xia et al. (2004) in Dai (2010) stated that when customers discover disadvantage, inequality, and unfited price, fairness perception could trigger negative emotions such as disappointment and anger which may lead to negative consequence of behavioral intentions (e.g. intention to spread negative word of mouth, complaints, switching to competitor, etc.). Xia et al. (2004) said that consumer assessments of whether a seller's price can be reasonably justified are considered as the perceived price fairness. When customers believe that the seller gives fair price for the service or product, they intent to repeat and buy the product again. Gunmesson (2002) said that the customer perception of price fairness influences the perceived value, satisfaction, and it produces different emotion and behavioral response.

Some previous studies on customer behavior and its interrelationship with customer value and satisfaction have been done, for example, Wahyuningsih (2011) had investigated the relationship among customer value, satisfaction and behavioral intention of car insurance. Phuong and Trang 
(2018) had investigated the relationship of perceived service quality, perceived system quality, and information quality towards repurchase intention on Grab and Uber customers. Therefore, this study fit the gap in analyzing the elements of customer satisfaction, perceived service quality, perceived product quality and perceived price fairness in automobile car service business especially in Indonesia (particularly Toyota Authorized Service Garage). Considering the level of car growth, high number of car in Indonesia, and number of car repair service, the managers and business owners need to know the behavioral perception of their customers especially the repurchase intention in order to enlarge their competitive advantage. Furthermore, this study is intended to fill these gaps, which means that managers will be able to access the major variabel affecting customer repurchase intention. Managers should be able to build strategic marketing decision to improve company marketing and earning oppotrinity. For further research, this study should be able to contribute basic customer perceived behaviour in Toyota service garage that can be applied in other service garage brands.

To invoke the customers' willingness to repeat order and repurchase the car service in the same dealer, business owners or managers must fill in customer expectation. However, customer expectation often does not meet the business reality, and sometimes customer value regarding service quality, product quality and price fairness change overtime, which makes it more difficult to fulfill. Therefore, this study focused to determine the relationship between behavioral intention with customer repurchase intention, customer satisfaction, perceived service quality, perceived product quality and perceived price fairness in automobile industry, particularly in service garage.

\section{LITERATURE REVIEW}

\section{Perceived Service Quality}

Perceived service quality has been defined by Czepiel (1990) as customers' perception of how good and rigorous a service meets or exceeds the expectation. To build the perception about quality of service is a long term process which is determined by quality of the service (Ismoyo et al., 2017). The quality of service was helped company to increase the market share if perceived service quality meets or over the expectation, and vice versa (Anderson and Zeithanml, 1984, as cited in Hussain, Bhatti and Jilani, 2011). Therefore, in the modern era, the high competition in business leads the managers to redefine their strategy to compete with their competitors and to focus their attention on service quality (Thamnopoulos, Tzetziz and Laois, 2012). Customers will consider to choose a service or product because of personal perception regarding superiority and perfection of the given product or service.

In automobile repair service business, the excellent service which is given by company to the customers is an essential success element to survive and win the high competition (Hussain, Bhatti and Jilani, 2011). The customers may have many choices to repair their car in any workshop based on their preference which can fulfill their expectation, but they need an excellent service for their car. Eventually after purchasing, the customersare attracted more to a good after-care and maintenance service. They will confirma better engagement with the service garagethan with the dealer where they gought the car (DMA Foresight factory research, 2017). If the customers enjoy the service experience, they will normally return to the provider and may bring along friends and colleagues. On the other hand, dissatisfied customers will share their experience with others and organization, and never know what is going on to hit after (Bowman and Narayadas, 2001).

Soon et al. (2014) said that automobile company should always perform good quality car service, show high responsiveness, care, and solve the car problem faced by the customer promptly, so the customers are confident about the integrity of the company. The company also has to make sure that the car has a good performance on the road after service. Customers come to the automobile repair workshop with a hope that their car problem can be solved by the workshop and 
Yafet Eka Prasetya and Julfree Sianturi (2019). "Customer repurchase intention in service business: a case study of car repair service business", Management and entrepreneurship: trends of development, 2 (08), pp. 18-34. doi: https://doi.org/10.26661/2522-1566/2019-2/08-02

will not face the same problem in the future. Therefore, the workshop should make sure all problems that the customers bring have been solved completely. Shammaryi\& Samerkanina (2014) in their research concluded that car owners expect to receive excellent quality of service not only while the purchasing process is going on, but also after the car has been purchased. In addition, it is also said that today's customers expect to receive an automatic reminder when their vehicles' periodic service is duein order to book a service appointment easily as well as to receive personal treatment.

The processes of delivering services determine the quality of service and pivotal for the customers to gather their notion about the perceived service quality (Cronin et al., 2000; Parasuraman, 2000). Hussain, Bhatti and Jilani (2011) concluded in their study that delivery time, process, promise commitment of installation, and warranty showed direct relation with customer satisfaction. Based on those studies, it can be summarized that car owners who come to automobile repair expect their car to be maintained with an excellent process, on time delivery, and all of their car problems are completely solved.

Acording to the studies above and some previous researchconducted by Mensah (2018), Phuong and Trang (2018), Ismoyo et al. (2017), Al-Shamari and Kanina (2014), Ismail and Yunan (2016), Izogo and Ogba (2014) which altogether found that service quality has positive and significant impact toward customer satisfaction and purchase intention, the researchers statedthe first hypothesis for this research regarding the perceived service quality as follows:

H1: Perceived service quality has positive and significant effect towardscustomer satisfaction.

\section{Perceived Price Fairness}

Perceived price fairness is defined as consumers' subjection assessment of whether the difference between a seller's price and the price of other parties is reasonable, acceptable, or justifiable (Bolton et al., 2003). Itis said that price fairness is a process that is recognized by customers as an outcome which is reasonable and acceptable. Moreover, the influence of customers' perceived price fairness will depend on the offer price that the customers received. Dai (2010) argued that fairnessis very subjective since it is based on what the customers perceived regardless the perception is correct or not. Therefore, price fairness is a critical element until the customers perceive anunfair price (Dai, 2010).

Pricing is very important for the company to reach the profit and to keep the existence in the competitive market. Management should be careful to determine the price because the price affects the sales and the acceptance of product in the market. Moreover, price also provides link between quality of service and customer expectation (Bassey, 2014). It means that higher price will be followed by higher expectation from the customers to get better quality of service and experience of product.

A finding in 2005 from a study conducted by Homburg, Koschate, and Hoyer revealed the existence of strong positive impact of customer satisfaction on willingness to pay. Thus, the customers who are satisfied with the service in the past will not only seek for the service provider in the future, but also have willingness to pay premium price for the service. Lindgreen et al. (2000) said that retained customers may pay higher price than newly acquire customers, and less likely to receive discounted offer that are often made to acquire new customers. The study of Homburg et al. (2005) was strengthened by the study of Soon et al. (2014) which mentioned that car buyers will value the quality of service and product more than the chargedprice since it is high involvement product. Agyapong and Ghana (2011) said that most customers prefer good service than lower price since they are willing to pay a little extra to get better or more efficient services.

Based on some studies mentioned in the previous paragraph, the researchers hypothesized that:

H2: Perceived price fairness has positive and significant effect towards customer satisfaction. 


\section{Perceived Product Quality}

Perceived product quality is an important element of the marketing strategies which aims to build brand image and increase the market share (Tsioutsou, 2005). Perceived quality is the consumers' judgement about a product's overall excellence or superiority (Zeithaml, 1988 in Tsioutsou, 2005). Perceived product quality is related to superiority of product or service which customers experienced when using the product or service to satisfy their needs (Kottler etal., 2002 in Saleem et al., 2015). Customers calculate product superiority in term of how much happiness they received from that product (Jiang and Wang, 2006). Consumers will find the product which can fulfill the whole supremacy and excellence (Zeithaml, 1988). Therefore, perceived products quality will drive the customers' perception to decide purchasing a product when the value and core function meet their needs.

Perceived quality is a global assessment ranging from "bad" to "good", characterized by high abstraction level and refers to specific consumption setting (Tsioutsou, 2005). Before going to purchase a product, customers have a perception about product quality, price and appearance, but after using a product, purchase intention increases or decreases depending on their experience when using the product. Rust and Oliever (1994) in Tsioutsou (2005) argued that perceived quality is both pre and post purchase construct. Customers consider perceived quality as more specific concept based on the product or service (Saleem et al., 2015).

In line with the studies before, the researchersstated a hypothesison perceived product quality that:

H3: Perceived product quality has positive and significant effect towards customer satisfaction.

\section{Customer Satisfaction}

Customer satisfaction can be written as the needs and goals to achieve a pleasure level of fulfillment and emotional response provided by a service (Olivier, 1997). It is a variable that is very important for an enterprise as strategic indicator, or for a company's success and long-term competitiveness (Anderson et al., 2008). The benefits of customer satisfaction are not limited to automobile industry. The benefits have been revealed as the following:

- Customer satisfaction has a direct and strong relation with customer loyalty. More satisfied customers are more loyal to the firm (Haq, 2012).

- The customer satisfaction is the most important part of any automobile service sector. Thus, the main job of service industry is to improve client satisfaction and quality of service which is helpful to improve the number of new clients (Kumar and Singh, 2016).

- Satisfied consumersare less likely to switch to other companies (Wahyuningsih, 2011)

- Customer satisfaction is an important element in delivering service for understanding and satisfying the customers' needs and wants, which further can increase market share resulting from the repeat purchases and referrals (Kotler, 2000).

- Customer satisfaction is very important as satisfied customers will add the value of the brand and spread a positive word of mouth as well as help in making good reputation of brand. Satisfied customers will be able to make long term profitable relationship with the brand (Hanif, Hafeez and Riaz, 2010).

In this study, in the first stage customer satisfaction functioned as dependent variable to three independent variables including perceived service quality, perceived product quality, and perceived price fairness. The second stage of the evaluation, customer satisfaction functioned as independent variable towards repurchase intention. 
Yafet Eka Prasetya and Julfree Sianturi (2019). "Customer repurchase intention in service business: a case study of car repair service business", Management and entrepreneurship: trends of development, 2 (08), pp. 18-34. doi: https://doi.org/10.26661/2522-1566/2019-2/08-02

Some researchers such as Zaw (2014), Soon et al. (2014), Mensah (2018), Lang Tang et al. (2015), said that when customer are satisfied will impact positively and significant towards repurchase intention. Thus, the researchers hypothesized that:

H4: Customer satisfaction has positive and significant effect towards repurchase intention.

\section{Repurchase Intention}

Repurchase is defined as a realized action of customers in buying or using the products again (Ibzan, Balarade and Jakada, 2016). Customers who buy or use a product or service for the first time will have potential to repeat purchase (Peyrot and Doren, 1994). Repurchase intention can be stated as "the individual's judgment about buying again a designation service from the same company, taking into account his or her current situation and likely circumstances" (Hellier et al., 2003). It is clear from the definition that customers will tend to repurchase if they have good experiences withthe products or services. Thus, it can also be mentioned that customers are more likely to repeat their transaction with the same company if they think that what they have received is worth what they have given up (Wahyuningsih, 2011). In this study, repurchase intention was obtained from surveys of current customers by assessing their tendency to purchase the same brand, same product or service from the same company.

\section{Chart of Hypothesis Statement}

Four hypotheses stated previously can be briefly depicted in the following chart:

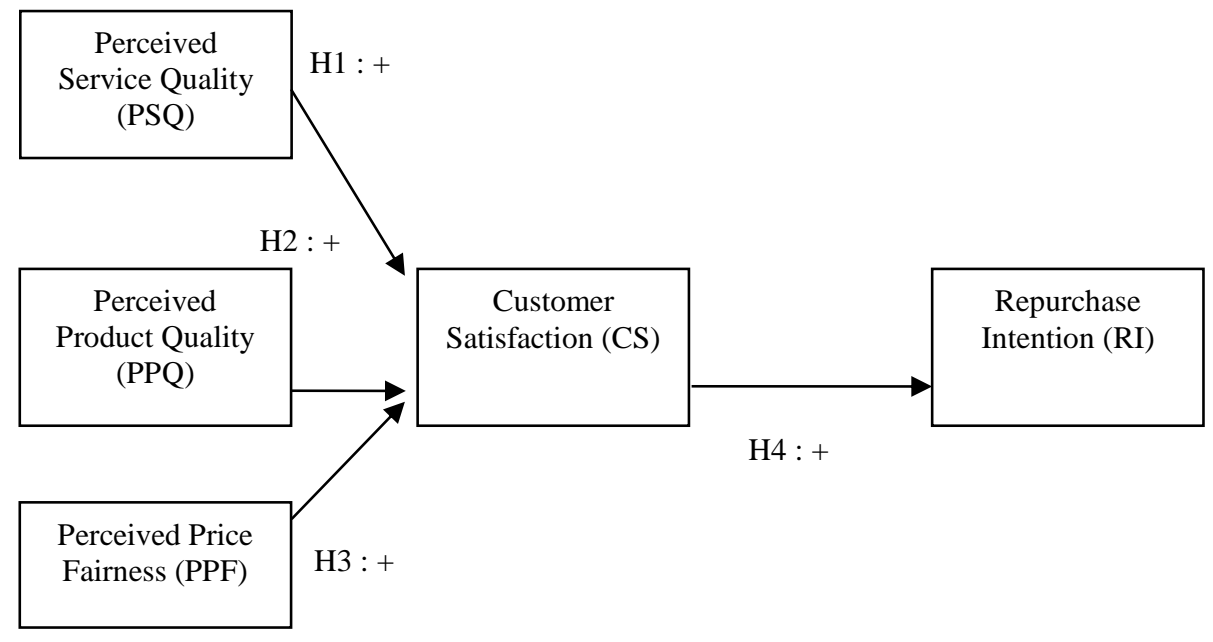

Figure 1. Chart of Hypothesis Statement

H1: Perceived service quality has positive and significant effect towards customer satisfaction. $\mathrm{H} 2$ : Perceived product quality has positive and significant effect towards customer satisfaction. H3: Perceived price fairness has positive and significant effect towards customer satisfaction. H4: Customer satisfaction has positive and significant effect towards repurchase intention. 


\section{METHODOLOGY}

\section{Data and Methodology}

The non-probability purposive sampling was performed to obtain the samples of this research. This method was targeting the people who own Toyota car and regularly use the service of authorized dealer workshop to repair and maintain their car.The valid samples collected were 174 from 200 surveys done by the researchers. The survey was conducted online in all over Indonesia, and in-site survey in several Toyota authorized dealers in North Sumatera. The main instrument of the data collection was the questionnaire which was adopted from previous researchers, Soon et al. (2014) and other researchers. The questions were closed-ended questions with a 5-points Likert scale, the scores were coded 5 for strongly agree, 4 for agree, 3 for neutral, 2 for disagree, and 1 for strongly disagree. The questionnaire was distribured for 2 weeks in November 2018 with $87 \%$ response (174 out of 200 survey).

The four set of variables were then tested to ensure the validity and reliability along with the assumption test to ensure the normality, linearity, homoscedasticity and multi-collinearity, which was concluded as powerful enough to be used for this research.

\section{Measurement of Independent Variables}

The study applied multi-items (instrument) scales to measure the model construct. Every variable was tested using three to five instruments with the following detail:

The measurement of perceived service quality (PSQ) was derived from the study by Soon et al. (2014). The existing instrument was considered suitable since it was dedicated for automobile industry which was in line with the objective of this study. Five instruments were questioned to capture as much as possible the spectrum of PSQ with the following list of questionnaire:

- $\quad$ Employees of Toyota garage always perform good quality car service to their customers

- Employees of Toyota garage show their high responsiveness towards customers' request when servicing their car

- $\quad$ Customers are very confident with the car service provided by Toyota

- Employees of Toyota garage show their caring to the customers when servicing their car

- Employees of Toyota garage always understand the car problems that the customers faced and able to solve the problems in time.

The second variable is perceived product quality (PPQ), in which the researchers measured the customers' point of view before purchasing the product, using the adopted instrument from the previous study (Stylidis et al., 2015). The PPQ was measured based on three major components which are related to visual quality, feeling quality, and overall performance. The overall questionnaire instrument was a combination of the studies by Stylidis et al. (2015) and Soon et al. (2014) with the following list of questionnaires:

- Toyota's products have the best performance

- $\quad$ Toyota garage always replaces the spare-part with a good quality spare-part.

- $\quad$ Product replacement such as oil machine and other spare parts by Toyota garage fulfill the customer expectation on product quality.

The instrument to measure the perceived price fairness was an adopted instrument used by previous researchers (Hermann et al., 2007 and Soon et al., 2014) which is intended to measure a relative comparison of product or service price with other competitors in the same environment. The construct was build based on fivequestionnaire instruments as follows:

- $\quad$ The price of Toyota service garage is reasonable 
Yafet Eka Prasetya and Julfree Sianturi (2019). "Customer repurchase intention in service business: a case study of car repair service business", Management and entrepreneurship: trends of development, 2 (08), pp. 18-34. doi: https://doi.org/10.26661/2522-1566/2019-2/08-02

- All customers pay the same price when they maintain their car in the same city with the same problem

- Toyota service garage and spare part is not overpriced.

- The price of Toyota service garage is in accordance with the quality of the service

- $\quad$ The price of Toyota service garage is acceptable compare to other service garages

\section{Measurement of Dependent Variables}

Customer satisfaction was measured by adopting instrument which was developed by Soon et al. (2014) with the main focus questionnaire on overall satisfaction performance, and willingness to spread positive word of mouth advertisement, the questionnaires were listed below:

- I am very satisfied with overall performance of Toyota garage

- I believe that I make a good decision in using Toyota service garage

- I will spread positive word of mouth about Toyota service garage to my relatives and friends.

The variable of repurchase intention as the final dependent variable to be tested measured the customer intention to use the same service repeatadly. The instrument used in this study was an adopted version of Rahman et al. (2014) and Soon et al. (2014) focusing on the intention of the customers to repeat the use of the service :

- I intent to return to use Toyota service garage

- I search for information about Toyota service garage from time to time

- I always talk about Toyota service garage with my friends

- I like to compare Toyota service garage to other brands from time to time

- I believe that Toyota garage and its products are the most suitable for me.

\section{FINDING AND DISCUSSION}

Table 1 describes the demographics of the respondents. It indicates that the majority of respondents' characteristic was male (68\%), aged between 31 to 40 years old (44\%) and worked as employees $(62 \%)$.

Table 1

Respondents' Demographics

\begin{tabular}{|c|c|c|}
\hline Respondents' Characteristics & Sub Profile & Percentage (\%) \\
\hline Gender & Male & $68 \%$ \\
\hline & Female & $32 \%$ \\
\hline Age & Less than 20 & $2 \%$ \\
\hline & $20-30$ years old & $15 \%$ \\
\hline & $31-40$ years old & $44 \%$ \\
\hline & More than 40 & $39 \%$ \\
\hline Occupation & Employee & $62 \%$ \\
\hline & Entrepreneur & $24 \%$ \\
\hline & House Wife & $6 \%$ \\
\hline & Student & $5 \%$ \\
\hline & Pensioner & $2 \%$ \\
\hline & Military and Police & $2 \%$ \\
\hline
\end{tabular}

Source: own study 
Respondents' demographics shows that the majority of the respondents wasadult people who had enough critical thinking to give their proportional review on the service based on their experiences. Convergent validity is based on the guidelines assessment proposed by Hair et al. (2009) where the construct is valid when KMO test indicates value of greater than 0.7. Table 2 describes the validity of all constructs with KMO value of 0,702 to 0,863 .

Table 2

Validity Test

\begin{tabular}{|c|c|c|c|c|c|c|}
\hline Variable & KMO Test & $\begin{array}{c}\text { Bartlett's } \\
\text { Test }\end{array}$ & $d f$ & Sig & $\begin{array}{c}\text { Standard } \\
\text { (Hairetal,2009) }\end{array}$ & Validity \\
\hline PPSQ & 0,863 & 348,742 & 10 & 0,000 & $\geq 0,7$ & Valid \\
\hline PPQ & 0,702 & 166,696 & 3 & 0,000 & $\geq 0,7$ & Valid \\
\hline PPF & 0,843 & 488,274 & 10 & 0,000 & $\geq 0,7$ & Valid \\
\hline CS & 0,730 & 298,426 & 3 & 0,000 & $\geq 0,7$ & Valid \\
\hline RI & 0,728 & 334,393 & 3 & 0,000 & $\geq 0,7$ & Valid \\
\hline
\end{tabular}

Source: own study

Cronbach's Coefficient Alpha test (between 0-1) was applied to describe the reliability of all factors. The variables are considered acceptable and reliable when the calculation result is greater than or equal to 0.60 (Sekaran, 1992). In this study, the measure model contained 5 latent variables and 21 measurements.

Table 3

Reliability Test

\begin{tabular}{|c|c|c|c|c|}
\hline Variable & Cronbach's Alpha & N of Item & $\begin{array}{c}\text { Standard (Sekaran and } \\
\text { Bougie, 2013) }\end{array}$ & Reliability \\
\hline PPSQ & 0.856 & 5 & 0.6 & Reliable \\
\hline PPQ & 0.802 & 3 & 0.6 & Reliable \\
\hline PPF & 0.889 & 5 & 0.6 & Reliable \\
\hline CS & 0.884 & 3 & 0.6 & Reliable \\
\hline RI & 0.858 & 5 & 0.6 & Reliable \\
\hline
\end{tabular}

Source: own study

Table 3 shows that the reliability test of five latent variables was above 0.7 which provides indication of reliable acceptance. Since the reliability, validity, and four classic tests had been passed, the data analysis was proceed to the first stage of linier regression by analysing the impact of three independent variables including perceived service quality (PPQ), perceived product quality (PPQ), and perceived price fairness (PPF) towards dependent variable of customer satisfaction (CS). Multi-regression analysis method was applied with a confidence level of $95 \%$ and alpha 0.05 . Using IBM-SPSS software, the results are described in the following table.

Table 4

\section{Model Summary of Customer Satisfaction Variable}

\begin{tabular}{|l|c|c|c|c|}
\hline \multicolumn{5}{|c|}{ Model Summary $^{b}$} \\
\hline Model & $R$ & $R$ Square & $\begin{array}{c}\text { Adjusted } R \\
\text { Square }\end{array}$ & $\begin{array}{c}\text { Std. error of the } \\
\text { Estimate }\end{array}$ \\
\hline 1 & $.776^{\mathrm{a}}$ & 0,603 & 0,596 & 0,39615 \\
\hline a. Predictors: (Constant), PPF, PSQ, PPQ \\
\hline
\end{tabular}

Source: own study 
Yafet Eka Prasetya and Julfree Sianturi (2019). "Customer repurchase intention in service business: a case study of car repair service business", Management and entrepreneurship: trends of development, 2 (08), pp. 18-34. doi: https://doi.org/10.26661/2522-1566/2019-2/08-02

The first linier regression between PSQ, PPQ, and PPF as independent variables with CS as dependent variable showed that $60 \%(\mathrm{R} 2=0.6)$ of customer satisfaction could be explained by the three independent variables, and the rest $40 \%$ would be explained by other variables which are out of the scope of this study.

Table 5

\section{ANOVA}

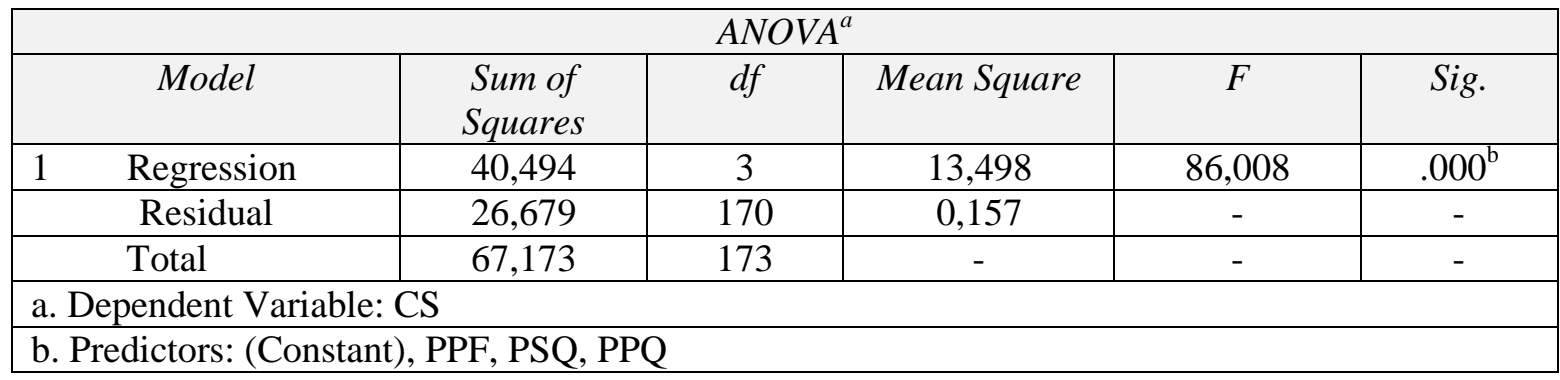

Source: own study

The simultaneous test of all independent variables indicated the result of $F$ values of 86,008 with significance of $0.000(<0.05)$. It concluded that the three independent variables are good predictors of customer satisfaction simultaneously.

Table 6

\section{Coefficients Regression}

\begin{tabular}{|c|c|c|c|c|c|c|c|c|}
\hline \multicolumn{9}{|c|}{ Coefficients $^{a}$} \\
\hline & \multirow[t]{2}{*}{ Model } & \multicolumn{2}{|c|}{$\begin{array}{c}\text { Unstandardized } \\
\text { Coefficients }\end{array}$} & \multirow{2}{*}{$\begin{array}{c}\begin{array}{c}\text { Standardized } \\
\text { Coefficients }\end{array} \\
\text { Beta }\end{array}$} & \multirow[t]{2}{*}{$\mathrm{t}$} & \multirow[t]{2}{*}{ Sig. } & \multicolumn{2}{|c|}{ Collinearity Statistics } \\
\hline & & $B$ & Std. Error & & & & Tolerance & VIF \\
\hline 1 & (Constant) & 0,506 & 0,243 & - & 2,086 & 0,038 & - & - \\
\hline & PSQ & 0,345 & 0,076 & 0,308 & 4,529 & 0,000 & 0,506 & 1,977 \\
\hline & PPQ & 0,208 & 0,076 & 0,196 & 2,738 & 0,007 & 0,456 & 2,192 \\
\hline & PPF & 0,332 & 0,055 & 0,391 & 6,045 & 0,000 & 0,559 & 1,788 \\
\hline
\end{tabular}

Source: own study

From the regression test, coefficient of independent variable of perceived of service quality toward dependent variable of customer satisfaction was 0,345 with $t$ value 4,529 and level of significant $0.000<0.05$. Thus, hypothesis null is rejected and $\mathrm{H}_{1}$ is accepted. It means that there is a positive and significant impact of perceived service quality toward customer satisfaction. Every change of perceived service quality variable by 1 scale will increase customer satisfaction by 0.34 . The findings are in line with the research from Mensah (2018), Phuong and Trang (2018), Ismoyo et al. (2017), Al-Shamari and Kanina (2014), Ismail and Yunan (2016), Izogo and Ogba (2014),in which perceived service quality has strong and positive impact towards customer satisfaction.

The test regression coefficient of variable perceived product quality towards dependent variable customer satisfaction showed coefficient regression of 0.208 with $\mathrm{t}$ value 2.738 and level of significant $0.007(<0.05)$. This result means that hypothesis null is rejected and $\mathrm{H}_{2}$ is accepted.

There is a positive and significant effect of perceived product quality towards customer satisfaction. Every change of perceived product quality variable by 1 scalewill increase customer satisfaction by 0.208 . The findings are also in line with research result from Tsoutsou (2005) and Saleem et al. (2015) which found a positive and significant impact of perceived product quality toward customer satisfaction. 
The test regression coefficient of variable perceived of price fairness toward dependent variable customer satisfaction showed coefficient regression 0.332 with t value 6.045 and level of significant $0.000(<0.05)$. This result means that hypothesis null is rejected and $\mathrm{H}_{3}$ is accepted. There is a positive and significant effect of perceived price fairness toward customer satisfaction. Every change of perceived price fairness variable by 1 scale will increase customer satisfaction by 0.332.These findingsare in line with the research dinding from Dai (2010) and Bassey (2014).

The linier equation is served below:

$$
\mathrm{CS}=0.506+0.345 . \mathrm{PSQ}+0.208 . \mathrm{PPQ}+0.332 . \mathrm{PPF}
$$

Individually, by comparing the constant value of each variable, PSQ had the most positive relationship with customer satisfaction, followed by PPF and PPQ. Furthermore, the second stage of the hypothesis analysis in this study is assessing the impacts of customer satisfaction towards repurchase intention by using linier regression technique.

Table 7

Model Summary of Repurchase Intention Variable

\begin{tabular}{|l|c|c|c|c|}
\hline \multicolumn{5}{|c|}{ Model Summary $^{b}$} \\
\hline \multicolumn{1}{|c|}{ Model } & $R$ & $R$ Square & $\begin{array}{c}\text { Adjusted } R \\
\text { Square }\end{array}$ & $\begin{array}{c}\text { Std. error of the } \\
\text { Estimate }\end{array}$ \\
\hline 1 & $.761^{\mathrm{a}}$ & 0,579 & 0,576 & 0,42658 \\
\hline a. Predictors: (Constant), CS & & \\
\hline
\end{tabular}

Source: own study

Table 7 shows that $\mathrm{R}$ square valuewas 0.579 , it means that repurchase intention as dependent variable could be explained $58 \%$ by customer satisfaction as independent variable and the rest $48 \%$ was explained by other variable(s) outside this researchparameter.

Table 8

ANOVA

\begin{tabular}{|c|c|c|c|c|c|c|}
\hline \multicolumn{7}{|c|}{ ANOVA $^{a}$} \\
\hline & Model & $\begin{array}{l}\text { Sum of } \\
\text { Squares }\end{array}$ & $d f$ & Mean Square & $F$ & Sig. \\
\hline 1 & Regression & 43,028 & 1 & 43,028 & 236,450 & $.000^{\mathrm{b}}$ \\
\hline & Residual & 31,300 & 172 & 0,182 & - & - \\
\hline & Total & 74,328 & 173 & - & - & - \\
\hline \multicolumn{7}{|c|}{ a. Dependent Variable: RI } \\
\hline & ors: (Con & & & & & \\
\hline
\end{tabular}

Source: own study

Table 8 result shows $F$ values of 236.450 with significance of $0.000(<0.05)$, it indicates that the independent variables are good predictors of repurchase intention as dependent variable. 
Yafet Eka Prasetya and Julfree Sianturi (2019). "Customer repurchase intention in service business: a case study of car repair service business", Management and entrepreneurship: trends of development, 2 (08), pp. 18-34. doi: https://doi.org/10.26661/2522-1566/2019-2/08-02

Coefficients Regression of Repurchase Intention variable

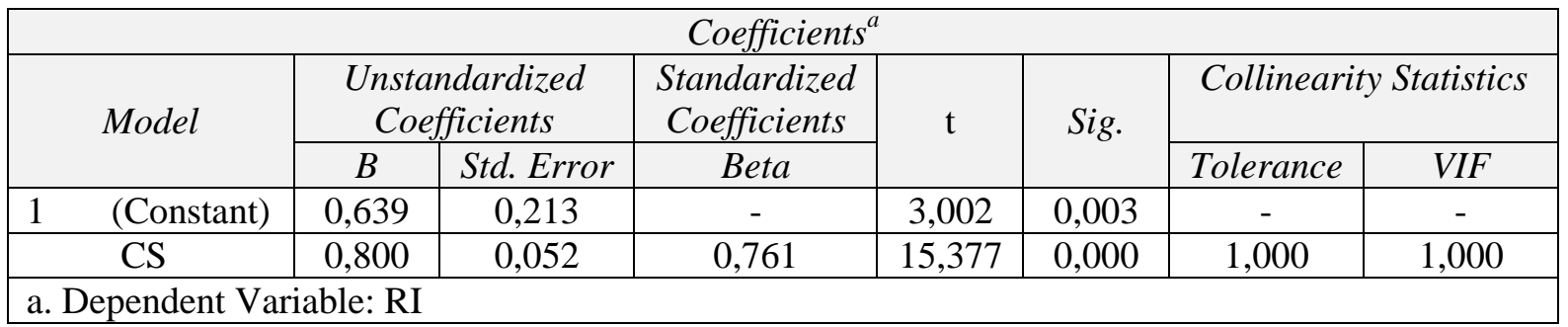

Source: own study

Hypothesis 4 is intended to prove the impact of customer satisfaction towards repurchase intention. Table 9 shows a regression coefficient of 0.800 with t value of 15.377 and significant level of $0.000(<0.05)$. This result means that hypothesis null is rejected and $\mathrm{H}_{4}$ is accepted. There is a positive and significant effect of customer satisfaction towards repurchase intention. Every change of customer satisfaction variableby 1 scale will increase repurchase intention by 0.800 . The linier equation is served below:

$\mathrm{RI}=0.639+0.8 . \mathrm{CS}$

The regression signifies the important relation between customer satisfaction with repurchase intention. The result confirms the result of some previous researches such as Zaw (2014), Soon et al. (2014), Mensah (2018), and Lang Tang et al. (2015).

\section{CONCLUSION}

The statistical analyses results have supported all hypotheses stated previously. The three variables PSQ, PPQ, and PPF were having positive and significant relationship towards customer satisfaction. In addition, among the three variables, perceived service quality is the most influential predictor to customer satisfaction. This study also successfully supports the hypothesis saying that customer satisfaction has positive and significant relationship towards repurchase intention. It can also be concluded that the foundations of repurchase intention of Toyota authorized service garage in Indonesia are perceived service quality, perceived product quality, perceived price fairness and customer satisfaction. Overall, the most likely outcome and further studiesare list of actions to be performed by the service garage dealer in persuading the customers in their behavioral perception sector tackling their perception of service quality, product quality, and price fairness.

However, a room of improvement on this study is identified from two corners; the first is enlarging the scope of the study by gathering more samples from different car brand and garage to have more general application. The second is targeting more explanation of dependent variables by adding other independent variable(s), signifies by R2 of around 0.6. The other $40 \%$ of customer satisfaction explanation should be studied further.

\section{RESEARCH IMPLICATION}

The results of this study can be used by automobile company especially Toyota dealer authorized service garage and possibly other car repair services in order to increase their rate or repurchase customers by paying attention on the three variables; PSQ, PPQ and PPF. The management should be more focused on the strategic programs to enhance the service quality for all level of employees from front line level to back office employees to increase the practice of high quality service. The management should drive every employee to serve beyond the expectation of the customers. Furthermore, the management must focus on improving product quality and keep the product reliable. When the product meets the needs of the customers, it will build a positive 
perception of the product and drive the customers to repeat the order. On the other hand, when the management wants to determine the price, they must formulate the price carefully to have fairness comparison with the quality of product and service with economic and profitability consideration.

\section{REFERENCES}

Agyapong, G.K. and Ghana, C. (2011). "The effect of service quality on customer satisfaction in utility industry - A case of Vodafone (Ghana)", International Journal of Business and Management, vol. 6, no. 5, doi:10.5539/ijbm.v6n5p203, Available at: https://pdfs.semanticscholar.org/0033/8218fb4cb7d14056032c55ffd0bb9cac9393.pdf (Accessed 12 May 2019).

Ahmad, R. and Buttle, F. (2010). "Customer retention: A potentially potent marketing management strategy", Journal of Strategic Marketing, Issue 9, pp. 29-45.

Anderson, S. (2008). "Linking customer satisfaction to the service concept and customer characteristic", Journal of Service Research, Issue 10 (4), DOI: 10.1177/1094670508314575

Aspinall, E., Nancarrow, C. and Stone, M. J. (2001). "The meaning and measurement of customer retention", Journal of Targeting, Measurement and Analysis for Marketing, vol. 10, issue 1, pp. 79-87. Available at: https://link.springer.com/article/10.1057/palgrave.jt.5740035 (Accessed 14 May 2019).

Balla, B., Ibrahim. S., and Ali, A. (2015). "The impact of relationship quality on repurchases intention towards the customers of automotive companies in Sudan", British Journal of Marketing Studies, vol. 3, no.4, pp. 1-15. Available at: https://www.researchgate.net/publication/281404899_THE_IMPACT_OF_RELATIONSHIP_Q UALITY_ON_REPURCHASE_INTENTION_TOWARDS_THE_CUSTOMERS_OF_AUTO MOTIVE_COMPANIES_IN_SUDAN (Accessed 15 May 2019).

Balamurugan, R.N., Sathish, M., Surinder, N. D. and Karthikeyan, P. (2013). "Customer relationship management in car service industry with reference to car dealers in Coimbatore", Journal of Business Management \& Social Sciences Research (JBM \& SSR), vol. 2 (6), pp.4349. Available at: http://www.borjournals.com/a/index.php/jbmssr/article/view/237/pdf (Accessed 15 May 2019).

Bassey, F. O. (2014). "The effect of perceived price fairness on customer satisfaction and loyalty", Podgorica, Master dissertation, Eastern Mediterranean University. Available at: https://pdfs.semanticscholar.org/e859/b7e8244e8e1006ca91dfacbe1623fd0ad48c.pdf (Accessed 17 May 2019).

Berndt, A. (2009). "Investigating service quality dimensions in South African motor vehicleservicing", African Journal of Marketing Management, vol. 1 (1), pp. 1-9. Available at: https://academicjournals.org/journal/AJMM/article-full-text-pdf/36AD9501830 (Accessed 10 May 2019).

Bowman, D. And Narayandas, D. (2001). "Managing customer-initiated contacts with manufactures: The impact on share of category requirements and word-of-mouth behavior", Journal of Marketing Research, vol. 38, no. 3, pp. 281-297

Buttle, F. (2009). Customer relationship management-concept \& technologies. CITY of publisher: Elsevier Ltd.

Bolton, L. E., Warlop, L. and Alba, J.W. (2003). "Consumer perception of price (un)fairness", Journal of Consumer Research, vol. 29, pp. 474- 491.

Boafo, D. N. (2015). "Effect of sales service quality on customer retention: A case study of PHC Motor Accra, Ghana", The International Journal of Business \& Management, vol. 3 (5).

CzepieI, J. A. (1990). "Service encounters and service relationships: Implications for research", Journal of Business Research, vol. 20, pp. 13-21. 
Yafet Eka Prasetya and Julfree Sianturi (2019). "Customer repurchase intention in service business: a case study of car repair service business", Management and entrepreneurship: trends of development, 2 (08), pp. 18-34. doi: https://doi.org/10.26661/2522-1566/2019-2/08-02

Cronin, J.J., Brady, M.K. and Hult,G. (2000). "Assessing the effects of quality value and customersatification on consumer behavioral intentions in service environments", Journal of Retailing, vol. 76 (2), pp. 193-215

Dai, Bo. (2010). The impact of perceived price fairness of dynamic pricing on customer satisfaction and behavioral intention: The moderating role of customer loyalty. Auburn: Auburn University

Dawkins, P.M. and Reichheld, F.F. (1990). "Customer retention as a competitive weapon", Directors \& Board Summer, vol. 42 (7), pp. 20-40.

Gummesson, E. (2002). Total relationship marketing. CITY of publisher: Butterworth-Heinemann.

Hair Jr, J. F., Anderson, R. E., Tatham, R. L., Babin, B. J. and Black, W. C. (2009). Multivariate data analysis (7th ed.). New Jersey: Prentice-Hall.

Hanif, M., Hafeez, S. and Riaz, A. (2010). "Factor affecting customer satisfaction", International Research Journal of Finance and Economics, issue 60, pp.44-52.

Haq, A. (2012). "Satisfaction towards customer loyalty in auto-mobile industry of Pakistan", Int. J. Manag. Bus. Res., 2 (4), pp. 363-371. Available at: https://www.researchgate.net/publication/279993624_Satisfaction_towards_Customer_Loyalty_ in_Auto-Mobile_Industry_of_Pakistan (Accessed 10 May 2019).

Hellier, P. K., Gus, G., Rodney A. C. and John, A. R. (2003). "Customer repurchase intention: A general structural equation model”, European Journal of Marketing, 37 (11/12): 1762-1800. DOI: $\quad 10.1108 / 03090560310495456 . \quad$ Available at: https://www.researchgate.net/publication/242342933_Customer_Repurchase_Intention_A_Gene ral_Structural_Equation_Model (Accessed 12 May 2019).

Homburg, C., Koschate, N. and Hoyer, W. D. (2005). "Do satisfied customers really pay more? A study of the relationship between customer satisfaction and willingness to pay", Journal of Marketing, vol. 69, no.2, pp. 84-96. https://doi.org/10.1509/jmkg.69.2.84.60760

Hussain, N., Bhatti. W.A., and Jilani, A. (2011). "An empirical analysis of after sales service and customer satisfaction", Management \& Marketing Challenges for the Knowledge Society, vol. 6, no. 4, pp. 561-572. Available at: https://www.academia.edu/9712352/An_empirical_analysis_of_after_sales_service_and_custom er_satisfaction (Accessed 18 May 2019).

Ibzan, E., Balarabe, F. and Jakada, B. (2016). "Customer satisfaction and repurchase intentions", Developing Country Studies, vol. 6, pp. 96-100.

Ismoyo, N., Hadiwidjojo, D., Rahman, F.and Rahayu, M. (2017)."Service quality perception's effect on customer satisfaction and repurchase intention", European Business \& Management, vol. 3 (3), pp. 37-46.

Ismail, A., Sufardi, Y. and Yunan, M. (2016). "Service quality as a predictor of customer satisfaction and customer loyalty", Scientific Journal of Logistic, vol. 12 (4), pp. 269-283.

Izogo, E.E. and Ogba, I. (2015). "Service quality, customer satisfaction and loyalty inautomobile repair servicessector", International Journal of Quality \& Reliability Management, vol. 32, pp. 250-269

Jiang, Y. and Wang, C.L. (2006). "The impact of affecton service quality and satisfaction: The moderationof service contexts", Journal of Services Marketing, vol. 20 (4), pp. 211-218. Available at: http://dx.doi.org/10.1108/08876040610674562 (Accessed 18 May 2019).

Kotler, P. (2000). Marketing management: The millennium edition, pp. 153-155.

Kumar, A. and Singh, B. (2016). "Role of customer satisfaction in automobile service sector", International Journal of Engineering Technology, Management and Applied Sciences, vol. 4 (10).

Lang Tang, L., Han Shu, C. and Wen Chan, Y. (2015). Constructing a B2C repurchase intention model based on consumer perception factors.

Megatef, S. G. and Tomalieh, E. F. (2015). "The impact of customer loyalty program on customer retention", International Journal of Business and Social Science, vol. 6, no. 8 (1), p. 78-93. 
Available at: http://ijbssnet.com/journals/Vol_6_No_8_1_August_2015/8.pdf (Accessed 28 May 2019).

Mesnah, R. (2018). "Effect of service quality and customer satisfaction on repurchase intention in restaurant on University of Cape Coast campus", Journal of Tourism, Heritage and Service Marketing, vol. 4 (1), pp. 27-36. Available at: https://www.jthsm.gr/vol4iss1/4-1-5.pdf (Accessed 23 May 2019).

Olivier, R. (1997). Satisfaction: A behavior perspective on the customer. Maidenhead: McGrawHill.

Parasuraman, A., Zeithaml, V.A. and Berry, L. L. (1985). "A conceptual model of service qualityand its implications for future research", Journal of Marketing, vol. 49(4), pp. 41-50.

Peyrot, M. and Doren, D. (1994). "Effect of a class action suit on consumer repurchase intentions", Journal of Consumer Affairs, vol. 39, pp. 361-379.

Phuong, N. and Trang, T. (2018). "Repurchase intention: The effect of service quality, system quality, information quality, and customer satisfaction as mediating role: a PLS approach of mcommerce ride hailing service in Vietnam", Marketing and Branding Research, vol. 5, pp. 7891. Available

at: https://www.researchgate.net/publication/325708845_Repurchase_Intention_The_Effect_of_Ser vice_Quality_System_Quality_Information_Quality_and_Customer_Satisfaction_as_Mediating _Role_A_PLS_Approach_of_M-Commerce_Ride_Hailing_Service_in_Vietnam (Accessed 20 May 2019).

Saleem, A., Ghafar, A., Ibrahim, M., Yousuf ,M. and Ahmed, N. (2015). "Product perceived quality and purchase intention with customer satisfaction", Global Journal of Management and Business Research: E Marketing, vol. 15 (1), pp.21-27. Available at: https://www.academia.edu/29725607/Product_Perceived_Quality_and_Purchase_Intention_with _Consumer_Satisfaction_Product_Perceived_Quality_and_Purchase_Intention_with_Consumer Satisfaction (Accessed 22 May 2019).

Soon, W.L., Run, E. and Hong, N. M. (2012). "Customer retention model - A case study of branded passenger car", Conference Paper, Conference: International Engineering and Management Conference 2012. Available at: https://www.researchgate.net/publication/236204251 (Accessed 28 May 2019).

Tsioutsou, R. (2005). "Perceived Quality Levels and Their Relation to Involvement, Satisfaction and Purchase Intention", Marketing Bulletin, vol. 16, Research Note 4.

Wahyuningsih (2011). "Customer value, satisfaction and behavioral intentions: The effect of customer search behavior", Asean Marketing Journal, vol. 3. Available at: http://journal.ui.ac.id/index.php/amj/article/view/2011 (Accessed 29 May 2019).

Wulf, K. D., Schroder, G. O., Cannier, M. H. and Oppen, C. V. (2003). "What drives consumer participation to loyalty programs? A conjoint analytical approach", Journal of Relationship Marketing, vol. 2 (1/2), pp. 69-83.

Zaw, A. and Chaipoopirutana, S. (2014), "Factors affecting customer loyalty of Toyota Cars' owners in Yangon, Myanmar", International Conference on Business law and corporate Social Responsibility.

Zeithaml, V. A. (1988). "Consumer perceptions of price, quality and value: A means-end modeland synthesis of evidence", Journal of Marketing, vol. 52, pp. 2-22. 
Yafet Eka Prasetya and Julfree Sianturi (2019). "Customer repurchase intention in service business: a case study of car repair service business", Management and entrepreneurship: trends of development, 2 (08), pp. 18-34. doi: https://doi.org/10.26661/2522-1566/2019-2/08-02

\section{ДОСЛІДЖЕННЯ КУПІВЕЛЬНОЇ ПОВЕДІНКИ У СФЕРІ ОБСЛУГОВУВАННЯ НА ПРИКЛАДІ КОМПАНІЇ АВТОМОБІЛЬНОГО СЕРВІСУ}

YAFET EKA PRASETYA, магістрант факультету менеджменту, Університет Бінус, Західна Джакарта, Індонезія

JULFREE SIANTURI, магістрант факультету менеджменту, Університет Бінус, Західна Джакарта, Індонезія

Метою даного дослідження є визначення взаємозв'язку між купівельною поведінкою і наміром клієнта в питанні придбання та подальшого викупу продукції, а також задоволеністю споживача одержуваною якістю обслуговування, якістю продукту i передбачуваною справедливою ціною в автомобільній промисловості, особливо в сфері послуг. Дане дослідження проводилося в спеціалізованих авторизованих автомобільних майстернях в Індонезії. 3 метою отримання даних для проведення дослідження, була проведена імовірнісна цільова вибірка. Опитування проводилося в режимі онлайн 3 використанням основного інструменту збору даних - анкети, яка була перейнята від попередніх дослідників. Дані були отримані в ході опитування, яке проводилося протягом двох тижнів за участю 174 респондентів. Згодом були протестовані чотири набори змінних, щоб гарантувати достовірність і надійність проведених обчислень. В результаті даного дослідження було виявлено позитивний i значущий зв'язок одержуваної якості обслуговування, якості продукту і передбачуваною справедливою ціною з задоволеністю споживача. Крім того, на другому етапі було також доведено, що задоволеність клієнтів має істотний i позитивний взаємозв'язок 3 купівельною поведінкою і клієнтським наміром придбання і подальшого викупу продукції. Дане дослідження може бути покращено шляхом додавання критеріїв відбору, його збільшення, відповідно до дослідження купівельної поведінки по відношенню до різних марок автомобілів і подальшого вивчення додаткових залежних змінних. Проте, поточний результат надав цінні дані для автосервісу, які допоможуть збільшити активність купівельної поведінки.

Ключові слова: купівельна поведінка, намір викупу, задоволеність споживача, якість обслуговування, якість продукту, справедлива ціна.

\section{ИССЛЕДОВАНИЕ ПОКУПАТЕЛЬСКОГО ПОВЕДЕНИЯ В СФЕРЕ ОБСЛУЖИВАНИЯ НА ПРИМЕРЕ КОМПАНИИ АВТОМОБИЛЬНОГО СЕРВИСА}

YAFET EKA PRASETYA, магистрант факультета менеджмента, Университет Бинус, Западная Джакарта, Индонезия

JULFREE SIANTURI, магистрант факультета менеджмента, Университет Бинус, Западная Джакарта, Индонезия

Целью данного исследования является определение взаимосвязи между покупательским поведением и намерением клиента в вопросе приобретения и дальнейшего выкупа продукции, а также удовлетворенностью потребителя получаемым качеством обслуживания, качеством продукта и предполагаемой справедливой ценой в автомобильной промышленности, особенно в сфере услуг. Данное исследование проводилось в специализированных авторизованных автомобильных мастерских в Индонезии. С целью получения данных для проведения исследования, была произведена вероятностная целевая выборка. Опрос проводился в режиме онлайн с использованием основного инструмента сбора данных - анкеты, которая была перенята от предыдущих исследователей. Данные были получены в ходе опроса, который проводился в течение двух недель с участием 174 респондентов. Впоследствии были протестированы четыре набора переменных, чтобы гарантировать достоверность и надежность проводимых вычислений. В результате данного 
исследования была обнаружена положительная и значимая связь получаемого качества обслуживания, качества продукта и воспринимаемой справедливой ценой с удовлетворенностью потребителя. Кроме того, на втором этапе было также доказано, что удовлетворенность клиентов имеет существенную и положительную взаимосвязь с покупательским поведением и клиентским намерением приобретения и дальнейшего выкупа продукции. Данное исследование может быть улучшено путем добавления критериев отбора, его увеличения, в соответствии с исследованием покупательского поведения в отношении различных марок автомобилей и дальнейшего изучения дополнительных зависимых переменных. Тем не менее, текущий результат предоставил ценные данные для автосервиса, которые помогут увеличить активность покупательского поведения.

Ключевые слова: покупательское поведение, намерение выкупа, удовлетворенность потребителя, качество обслуживания, качество продукта, справедливая цена. 